\title{
A Blood Biomarker for Duchenne Muscular Dystrophy Shows That Oxidation State of Albumin Correlates with Protein Oxidation and Damage in Mdx Muscle
}

\author{
Basma A. Al-Mshhdani ${ }^{1}$, Miranda D. Grounds ${ }^{2}$, Peter G. Arthur ${ }^{1}$ and Jessica R. Terrill ${ }^{1, *}$ \\ 1 School of Molecular Sciences, The University of Western Australia, 35 Stirling Highway, Perth, WA 6009, \\ Australia; basma.al-mshhdani@research.uwa.edu.au (B.A.A.-M.); peter.arthur@uwa.edu.au (P.G.A.) \\ 2 School of Human Sciences, The University of Western Australia, 35 Stirling Highway, Perth, WA 6009, \\ Australia; miranda.grounds@uwa.edu.au \\ * Correspondence: jesssica.terrill@uwa.edu.au; Tel.: +61-8-6488-1211
}

Citation: Al-Mshhdani, B.A.; Grounds, M.D.; Arthur, P.G.; Terrill, J.R. A Blood Biomarker for Duchenne Muscular Dystrophy Shows That Oxidation State of Albumin Correlates with Protein Oxidation and Damage in Mdx Muscle. Antioxidants 2021, 10, 1241. https:// doi.org/10.3390/antiox10081241

Academic Editors: Luca Massaccesi, Carmela Rita Balistreri and Scott Powers

Received: 5 May 2021

Accepted: 29 July 2021

Published: 3 August 2021

Publisher's Note: MDPI stays neutral with regard to jurisdictional claims in published maps and institutional affiliations.

Copyright: (c) 2021 by the authors. Licensee MDPI, Basel, Switzerland. This article is an open access article distributed under the terms and conditions of the Creative Commons Attribution (CC BY) license (https:// creativecommons.org/licenses/by/ $4.0 /)$.

\begin{abstract}
Duchenne muscular dystrophy (DMD) is a severe X-linked muscle wasting disease with no cure. While the precise mechanisms of progressive dystropathology remain unclear, oxidative stress caused by excessive generation of oxidants is strongly implicated. Blood biomarkers that could track oxidant levels in tissues would be valuable to measure the effectiveness of clinical treatments for DMD; our research has focused on developing such biomarkers. One target of oxidants that has the potential to be harnessed as a clinical biomarker is the thiol side chain of cysteine 34 (Cys34) of the blood protein albumin. This study using the $m d x$ mouse model of DMD shows that in plasma, albumin Cys34 undergoes thiol oxidation and these changes correlate with levels of protein thiol oxidation and damage of the dystrophic muscles. A comparison with the commonly used biomarker protein carbonylation, confirmed that albumin thiol oxidation is the more sensitive plasma biomarker of oxidative stress occurring in muscle tissue. We show that plasma albumin oxidation reflects muscle dystropathology, as increased after exercise and decreased after taurine treatment of $m d x$ mice. These data support the use of albumin thiol oxidation as a blood biomarker of dystropathology to assist with advancing clinical development of therapies for DMD.
\end{abstract}

Keywords: biomarkers; Cys34 albumin; thiol oxidation; oxidative stress; Duchenne muscular dystrophy; $m d x$ mice; ageing; exercise; taurine

\section{Introduction}

DMD is a fatal X-chromosome linked disease with an incidence of 1 in 3600-6000 male births (reviewed in [1]). DMD occurs as a consequence of mutations in the dystrophin gene that result in dysfunctional or missing dystrophin protein [2]. An absence of functional dystrophin in skeletal muscles leads to membrane fragility and susceptibility to sarcolemma damage resulting in myofibre necrosis (myonecrosis) and severe loss of muscle mass over time (reviewed in [3-5]). While the precise mechanisms of myonecrosis and progressive dystropathology remain unclear, oxidative stress caused by excessive generation of oxidants has been widely implicated (reviewed in [6-9]).

Oxidants can affect cellular function in a number of ways. Hydroxyl radicals can irreversibly damage macromolecules such as proteins, and cause permanent loss of protein function $[10,11]$. However, other oxidants such as hydrogen peroxide $\left(\mathrm{H}_{2} \mathrm{O}_{2}\right)$ and hypochlorous acid $(\mathrm{HOCl})$ can oxidise thiols ( $\mathrm{RSH}$ ) of cysteine residues to form disulfides [12], reviewed in [7]. This is of interest because reversible oxidation of protein thiols has been shown to affect the function of many proteins including protein-protein interactions, signal transduction, regulation of gene expression and protein catabolism [7,13-15]. Additionally, unlike the irreversible damage caused by hydroxyl radicals, oxidation to disulfides is biologically reversible. 
Studies from our laboratory have investigated the location and consequences of oxidative stress in dystrophic muscle and have shown increased reversible protein thiol oxidation in animal models of muscular dystrophy; this is associated with muscle pathology including myofibre necrosis [8,10,14,16-18]. Moreover, drug treatments that decrease protein thiol oxidation are also very effective at reducing dystropathology in the mdx mouse model for DMD $[16,19]$. These data suggest a causative role of protein thiol oxidation in dystropathology.

There is interest in developing biomarkers that can track oxidative stress in various disease states, especially in biofluids such as blood, since access to human tissues is limited (reviewed in [20-23]). Popular blood biomarkers, such as the protein carbonyl assay or assays for products of phospholipid oxidation (isoprostanes, malondialdehyde, 4-hydroxynonenal) measure irreversible oxidative damage [24,25]. However, few studies have examined whether changes in such blood biomarkers of oxidative stress reflect changes in levels of oxidative stress and consequent damage in specific tissues [26-30]. Furthermore, no study has examined whether blood biomarkers of oxidative stress reflect changes in the levels of protein thiol oxidation in skeletal muscles. Previous studies have shown changes in protein thiol oxidation occurring in muscle tissue without commensurate changes in protein carbonyls, and MDA [10]. As a consequence, it is unlikely that measures of irreversible oxidation in blood would reflect changes in the levels of protein thiol oxidation in muscle.

Plasma albumin thiol oxidation is a potential biomarker of protein thiol oxidation in muscle tissue. While albumin is a plasma protein, the majority of albumin exists in the interstitium, as it moves from the blood across the capillary wall into the interstitial compartments, and returns to the blood through the lymphatic system [31]. It is consequently exposed to oxidants within tissue and can therefore potentially be used a biomarker of tissue oxidation. The cysteine residue 34 (Cys34) of albumin exists mostly in a reduced state in human plasma, but is susceptible to direct oxidation by oxidants or indirect oxidation via thiol/disulfide (SH/SS) exchange reactions [32,33]. The reduced thiol form of Cys34 represents $70-80 \%$ of total albumin in plasma of healthy adults (reviewed in [34,35]). The reversibly oxidized forms of albumin represent about 20-30\%, which present as a mixture of disulfides, with low molecular weight thiol compounds such as cysteine, cysteinylglycine, glutathione, homocysteine, and $\gamma$-glutamylcysteine [36], and reviewed in [11,37]). In addition, a small fraction (2-5\%) of albumin Cys34 exists in the biologically irreversibly oxidised sulfinic $\left(-\mathrm{SO}_{2} \mathrm{H}\right)$ and sulfonic acid $\left(-\mathrm{SO}_{3} \mathrm{H}\right)$ forms [38-40].

Oxidative modifications of serum albumin Cys34 have previously been investigated in various disease states, such as organ failure, kidney diseases, and diabetes mellitus, where increased percentages of reversibly and irreversibly oxidised plasma albumin Cys34 are reported [32,39,41-45] and exercise [46]. However, no previous study has examined whether an increase in the oxidation status of albumin (Cys34) is linked to increased oxidative stress or protein thiol oxidation in specific tissues.

We used the classic mdx mouse model of DMD to evaluate levels of plasma albumin oxidation as a measure of oxidative stress in dystrophic muscles. Young growing mdx mice undergo a period of peak muscle necrosis (myonecrosis) between 21-28 days and, after this acute growth, myonecrosis reduces and stabilises to a relatively low (although variable) level (approximately 6\% of each skeletal muscle) by about 8-12 weeks of age [17,47-50]. In adult mdx mice, exercise is used to increase myofibre damage and myonecrosis with associated increased levels of muscle creatine kinase (CK) in the blood [51-54] thus enabling potential therapeutic interventions to be more rigorously evaluated in vivo [16,17,49,50,55-57]; the effects of different types of exercise on mdx mice and DMD muscles are discussed in a recent review [58]. Few studies have investigated histopathology of mdx mice older than one year, with exception of several papers that report decline in health after one year with loss of body and muscle mass, extensive fibrosis of muscles and reduced lifespan [59-61]: from 78 weeks of age (corresponding to 18 months 
used in our study) the mdx mice had difficulty in obtaining food and water unaided, and they failed to groom themselves [59].

There is increasing interest in identifying and using blood biomarkers to monitor disease progression in mdx mice and DMD boys [62-64]. Therefore, in this study we examined the relationship between levels of protein thiol oxidation in muscles, to albumin thiol oxidation in plasma, of dystrophic mdx and control wild type C57Bl10scsn (C57) mice at various ages across their life-span (at 23 days, 6 and 12 weeks and 18 months). These ages were chosen on the basis of changes in muscle pathology, and to include ages that are routinely used experimentally. We also tested $\mathrm{mdx}$ mice subjected to a damaging short bout of treadmill exercise (at 6 weeks of age). To compare the sensitivity of albumin thiol oxidation relative to an established biomarker of oxidative changes, we measured protein carbonylation as a marker of irreversible protein oxidation (reviewed in [65]) in muscles and plasma, with correlation analysis performed to determine if plasma levels of albumin thiol oxidation and carbonylation reflect the tissue state. We also compared plasma levels of albumin thiol oxidation and carbonylation with plasma CK (a common blood readout of dystropathology), to see if plasma oxidation correlates with this measure of extent of muscle damage. In addition, to assess the use of plasma Cys34 albumin thiol oxidation as a potential readout of drug efficacy, muscle and plasma thiol oxidation was measured in young $\mathrm{mdx}$ mice treated with taurine (from 14 to 23 days). Taurine is an amino acid that protects dystrophic muscles from necrosis and decreases protein thiol oxidation in $\mathrm{mdx}$ muscles, as described by many papers from three independent groups [66-69]. These three experiments in mdx mice demonstrate the response of plasma Cys34 albumin thiol oxidation to changes in dystrophic muscle damage in $\mathrm{mdx}$ mice under various conditions.

\section{Materials and Methods}

All chemicals and reagents were purchased from Merck (Melbourne; Victoria; Australia) unless otherwise stated.

\subsection{Animal Procedures}

All experiments were carried out on dystrophic $\mathrm{mdx}(\mathrm{C} 57 \mathrm{Bl} / 10 \mathrm{ScSnmdx} / \mathrm{mdx})$ and normal wildtype control C57 (C57Bl/10ScSn) mice (the parental strain for mdx) from the Animal Resource Centre, Murdoch, Western Australia. Mice were maintained at the University of Western Australia under standard conditions, with free access to food and drinking water. All animal experiments were conducted in strict accordance with the guidelines of the National Health and Medical Research Council Code of practice for the care and use of animals for scientific purposes (2004), and the Animal Welfare act of Western Australia (2002), and were approved by the Animal Ethics committee at the University of Western Australia.

Mice underwent a single 30 min exercise session on a horizontal rodent treadmill (Columbus Instruments, Columbus, OH, USA), using an established protocol [17]. In brief, the protocol involved a settling (stationary) period for $2 \mathrm{~min}$, an acclimatisation with gentle walking period for $2 \mathrm{~min}(2 \mathrm{~m} / \mathrm{min})$, a warm-up period for $8 \mathrm{~min}(8 \mathrm{~m} / \mathrm{min})$ and the main exercise session of $30 \mathrm{~min}$ at a pace of $12 \mathrm{~m} / \mathrm{min}$. Mice were sampled immediately following the end of the exercise protocol.

\subsection{Taurine Treatment}

$\mathrm{Mdx}$ mice were treated with taurine from 14 days of postnatal age (prior to weaning and the acute onset of myonecrosis that occurs by 21 days), with soft chow containing $4 \%$ taurine. Untreated $\mathrm{mdx}$ and C57 mice had soft chow without taurine. Each group included pups $(n=8)$ with approximately equal male and female mdx pups, with all males for the C57 group. Mice were sampled at 23 days of age after 9 days of taurine treatment. 


\subsection{Blood and Tissue Collection for Oxidative Stress Analyses}

Mice were sampled at 23 days, 6 weeks, 12 weeks or 18 months of age, after cervical dislocation while under terminal anaesthesia ( $2 \% v / v$ Attane isoflurane, Bomac Animal Health, Hornsby, NSW, Australia). While mice were under terminal anaesthesia, whole blood was collected via cardiac puncture. Immediately, nine parts of blood was added to one part of trapping solution consisting of $62.5 \mathrm{mM}$ methoxypolyethylene glycol maleimide (malpeg, $5000 \mathrm{~g} / \mathrm{mol}$, JenKem Technology, Plano, TX, USA) in $40 \mathrm{mM}$ imidazole, pH 7.4 [46]. Blood samples with trapping solution were briefly vortexed and then centrifuged in a refrigerated centrifuged. Plasma was collected before incubating for another $20 \mathrm{~min}$ at room temperature before storage at $-80^{\circ} \mathrm{C}$ until analysis. The remaining blood was immediately centrifuged, plasma removed, and stored at $-80^{\circ} \mathrm{C}$ until biochemical analysis.

Quadriceps muscles were dissected and frozen immediately in liquid nitrogen and then stored at $-80^{\circ} \mathrm{C}$ for biochemical analysis.

\subsection{Protein Thiol Oxidation in Muscle}

Reduced and oxidised protein thiols were measured in quadriceps muscles using the two-tag technique as described previously [66]. In brief, frozen muscle was crushed under liquid nitrogen, before protein was extracted with $20 \%$ trichloroacetic acid (TCA)/acetone. Protein was solubilized in SDS buffer and protein thiols were labelled with the fluorescent dye BODIPY FL-N-(2-aminoethyl) maleimide (FLM, Invitrogen, Waltham, MA, USA). Following removal of the unbound dye using cysteine, protein was re-solubilized in SDS/Tris (0.5\% SDS, 0.5 M Tris, pH 7.0) and oxidized thiols were reduced with tris(2carboxyethyl)phosphine (TCEP) before the subsequent unlabelled reduced thiols were labelled with a second fluorescent dye Texas Red C2-maleimide (Texas red, Invitrogen). The sample was washed in 100\% TCA, followed by acetone, and resuspended in SDS buffer. Samples were read using a fluorescent plate reader (Fluostar Optima) with wavelengths set at excitation $485 \mathrm{~nm}$, emission $520 \mathrm{~nm}$ for FLM and excitation $595 \mathrm{~nm}$, emission $610 \mathrm{~nm}$ for Texas red. A standard curve for each dye was generated using ovalbumin and results were expressed per mg of protein, quantified using the DC Protein Assay (Bio-Rad, Gladesville, NSW, Australia).

\subsection{Plasma Albumin Thiol Oxidation}

The analysis of plasma thiol oxidation is summarised in Figure 1. Frozen plasma samples containing trapping solution were thawed at $37^{\circ} \mathrm{C}$ with agitation before splitting in half to become a reduced (R) sample and a non-reduced control protein sample (NRC). For the NRC aliquot, plasma was diluted (1/99) with SDS/Tris (as above). The R aliquot was diluted in half with $20 \mathrm{mM}$ L-cysteine hydrochloride monohydrate ( $\mathrm{pH} 3)$, followed by incubation at room temperature for $30 \mathrm{~min}$. The $\mathrm{R}$ aliquot was then diluted in half again with $25 \mathrm{mM}$ malpeg before a further incubation of $30 \mathrm{~min}$ at room temperature, and then diluted $(4 \mu \mathrm{L}$ in $99 \mu \mathrm{L})$ in SDS/Tris [46].

All samples were diluted 1 in 2 with loading buffer containing $0.187 \mathrm{M}$ Tris $\mathrm{pH} 6.8$, $4 \%$ SDS, $0.03 \% w / v$ bromophenol blue, and 30\% glycerol. Samples were resolved in $12 \%$ acrylamide gels containing 1\% $(v / v)$ of 2,2,2-trichloroethanol for fluorescent (Stain Free, Bio-Rad, Gladesville, NSW, Australia) imaging [70]. Gels were imaged using the StainFree imaging program on the ChemiDoc MP Imaging System (Bio-Rad), and loading was checked by measuring albumin signal.

Proteins were transferred to nitrocellulose membranes using the Trans Turbo Blot System (Bio-Rad). Membranes were washed three times with Tris-buffered saline containing Tween 20 (TBST) (10 mM tris, $150 \mathrm{mM} \mathrm{NaCl}, 0.1 \% v / v$ Tween 20, pH 7). All washing steps were carried out for 5 min with gentle agitation. Membranes were incubated with gentle agitation for $1 \mathrm{~h}$ with blocking buffer ( $5 \% \mathrm{w} / v$ skim milk powder in TBST) at room temperature and washed with TBST three times. Immuno-blotting was performed with antibodies to bovine serum albumin (Abcam, 192603, Cambridge, MA, USA) dissolved 1:5000 in TBST. Horseradish peroxidase conjugated goat anti-rabbit secondary antibodies 
(Thermo Fisher Scientific, Waltham, MA, USA) were diluted 1:10,000 in 5\% skim milk in TBST. The ChemiDoc MP Imaging System (Bio-Rad, Gladesville, NSW, Australia) was used to capture Chemiluminescence signal. ImageJ software was used to quantify the resultant images [71]. The background was subtracted, and edited for speckling and noise, before the image was inverted. Signal profile was measured using mean gray value of each band in the membrane. The linearity of signal was checked during method development. For normalisation, a common sample was loaded onto each gel. A quality control sample was used throughout method development, and was run on every gel analysed to ensure reproducibility. The coefficient of variation was $8.1 \%(n=5)$. All gels and blots are shown in the Supplementary Materials.

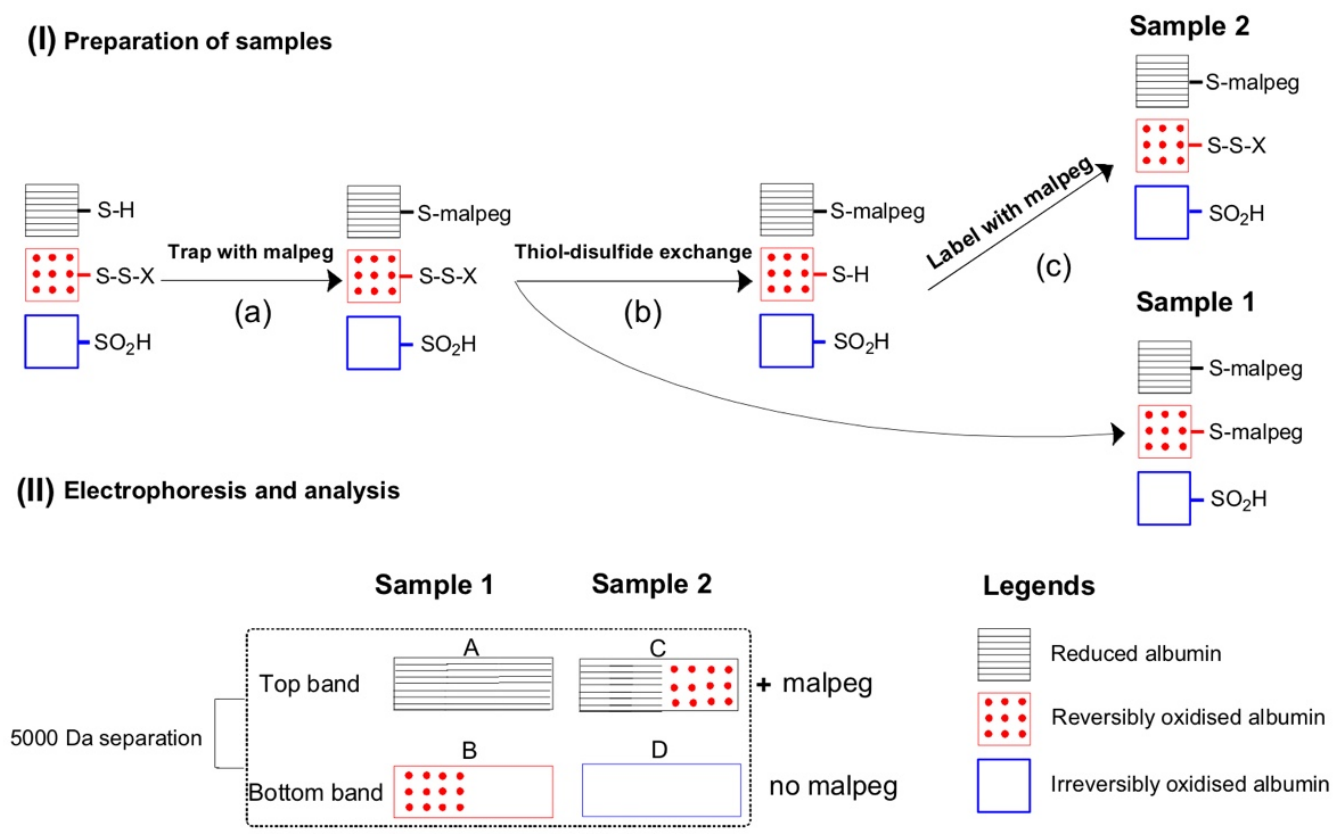

Figure 1. The measurement of irreversibly versus reversibly oxidized albumin Cys 34. (a) Represents available thiols (-S-H) in the plasma sample that are initially trapped with malpeg. (b) The sample is divided in two, with reversibly oxidised thiols (S-S-X) in the second sample converted to reduced thiols by thiol-disulphide exchange reactions and then (c) the reduced thiols are labelled with malpeg. Following electrophoresis, albumin bound to malpeg is separated by $5000 \mathrm{Da}$ figure.

\subsection{Protein Carbonylation in Muscle and Plasma}

Muscle protein carbonyl content was determined by using an immunoassay blot as described previously [72,73] with some modifications. In brief, TCA acetone extractions of quadriceps muscle, were washed with acetone, sonicated, and resuspended in SDS/Tris buffer, before normalisation of protein content using the DC Protein Assay. Muscle supernatants were diluted in extraction buffer to the same protein concentration $(1 \mathrm{mg} / \mathrm{mL})$. Two aliquots of protein extracts in SDS/Tris buffer were added into new microfuge tubes and to each $12 \%$ SDS was added. To one tube, $10 \mathrm{mM}$ 2,4-Dinitrophenylhydrazine (DNPH) in $10 \%$ trifluoroacetic acid was added, followed by a $15 \mathrm{~min}$ incubation at room temperature. Carbonyl groups (aldehydes and ketones) react with DNPH to form DNP bound proteins. To the other tube, serving as a negative control, 10\% trifluoroacetic acid was added. To all samples, neutralisation/loading solution (2 M Tris, 30\% glycerol, $0.02 \%$ bromophenol blue) was added, and then samples were loaded onto $4-15 \%$ PROTEAN ${ }^{\circledR}$ TGX precast gels (Bio-Rad).

To measure protein carbonyl in plasma, the following protocol was used. Frozen plasma samples were thawed, and then diluted 30 times with ice-cold 1\% NP40, $1 \mathrm{mM}$ EDTA in phosphate-buffered saline (PBS), supplemented with complete EDTA free protease inhibitor tablets (Roche, Sydney, Australia). Two aliquots of each plasma sample were diluted 1 in 2 with 6\% SDS. To one tube, $10 \mathrm{mM}$ DNPH in 10\% trifluoroacetic acid was 
added to a final DNPH concentration of $5 \mathrm{mM}$, before incubation for $15 \mathrm{~min}$ at room temperature. Following the addition of neutralisation solution, samples were diluted four times with loading buffer (without DTT). Plasma samples were further diluted 2 fold with $2 \times$ loading buffer before incubation at $95^{\circ} \mathrm{C}$ for $5 \mathrm{~min}$ and samples were resolved on $4-15 \%$ PROTEAN ${ }^{\circledR}$ TGX gels. A plasma sample from a C57 mouse was incubated with $1 \mathrm{mM}$ $\mathrm{HOCl}$ prior to DNPH labelling for use as a positive control.

For quantification of protein carbonyls in both muscle and plasma samples, gels were immunoblotted as described for albumin protein thiol oxidation, except the primary antibody was a rabbit whole antiserum antibody to DNP (D9656, Sigma, St. Louis, MI, USA) diluted 1:20,000 in TBST. Horseradish peroxidase conjugated goat anti-rabbit secondary antibody (Thermo Fisher Scientific) was diluted 1:25,000 in 5\% skim milk in TBST. Carbonyl content was calculated as a ratiometric value. In muscle, protein carbonyl was measured as the carbonyl density divided by the amount of fluorescence signal of the whole lane protein content from the stain free gel (arbitrary value). In plasma, albumin carbonyl was calculated as the carbonyl density divided by the amount of fluorescence signal of albumin from the stain free gel. For normalisation, a common sample was loaded onto each gel. All and blots are shown in the Supplementary Materials.

\subsection{Creatine Kinase (CK) Assay in Plasma}

Plasma CK activity reflects the leak of CK from muscles and is a classic measure of damage and necrosis of dystrophic muscles [73]. CK levels were measured in duplicate using the CK-NAC kit (Randox Laboratories, Parramatta, NSW, Australia), and analysed kinetically using a BioTek Powerwave XS Spectrophotometer using the KC4 (V34) program. In brief, plasma was diluted in $0.1 \% \mathrm{NaCl}$, before loading into a 96 well plate. Enzyme reagent was added and samples analysed for rate of absorbance change over $30 \mathrm{~min}$, every $1 \mathrm{~min}$, at $340 \mathrm{~nm}$ at $37^{\circ} \mathrm{C}$.

\subsection{Statistics}

Significant differences between groups were determined using GraphPad Prism software. Data were analysed using one-way ANOVA tests with post hoc testing, and all data are presented as mean \pm standard error of the mean (SEM). Significance was set at $p<0.05$. Pearson's correlation was used to assess the relationship between muscle and plasma parameters; all age groups were included in this analysis.

\section{Results}

\subsection{Protein Thiol Oxidation and Carbonylation in Muscles of C57 and Mdx Mice}

The percentage of protein thiol oxidation and carbonylation in muscle (quadriceps) was measured in C57 and mdx mice at 23 days (acute phase of myonecrosis), 6 weeks (initial myonecrosis has reduced and stabilised, approaching adult levels, with and without a single bout of treadmill exercise), 12 weeks (stable adult levels) and 18 months (myonecrosis has reduced further and fibrosis is extensive) (Figure 1). Protein thiol oxidation was higher in 23 day, 6 week and 12 week old mdx muscle compared with age-matched C57 muscle (Figure 2A). Treadmill exercise increased protein thiol oxidation 1.5 fold in 6 week old mdx muscle (Figure 2A). Muscle protein thiol oxidation was also compared between each time point for both strains; in C57 muscle protein thiol oxidation was comparable at 23 day and 6 week, however it increased 1.3 fold by 12 weeks. In mdx muscle, protein thiol oxidation decreased $40 \%$ from 23 days to 6 weeks, after which it increased 1.4 fold by 12 weeks. From 12 weeks to 18 months, muscle protein thiol oxidation decreased $17 \%$.

Protein carbonylation was 2.4 fold higher in 23 day old $\mathrm{mdx}$ muscle compared with age-matched C57 muscle (Figure 2B). No other difference in muscle protein carbonylation were observed. 


\subsection{Plasma Albumin Thiol Oxidation and Carbonylation in C57 and Mdx Mice}

Total albumin thiol oxidation was higher in 23 day, 6 week and 12 week old mdx plasma compared with age-matched C57 plasma (Figure 3A). Treadmill exercise had no effect on total albumin thiol oxidation in 6 week old mdx plasma (Figure 3A). In C57 plasma, total albumin thiol oxidation decreases $46 \%$ from 23 day to 6 weeks, however it increases 1.5 fold by 12 weeks (Figure $3 \mathrm{~A}$ ). In mdx plasma, total albumin thiol oxidation decreases $20 \%$ from 23 days to 6 weeks (Figure $3 \mathrm{~A}$ ).

There was no difference in reversible albumin thiol oxidation when comparing $\mathrm{mdx}$ plasma with age-matched C57 plasma (Figure 3B), and treadmill exercise had no effect on reversible albumin thiol oxidation in 6 week old mdx plasma (Figure 3B). In C57 plasma, reversible albumin thiol oxidation decreases $40 \%$ from 23 day to 6 weeks, and it increases 1.6 fold from 12 weeks to 18 months (Figure 3B). In mdx plasma, reversible albumin thiol oxidation decreases $36 \%$ from 23 days to 6 weeks (Figure 3B). Irreversible albumin thiol oxidation was 2.8 and 2 fold higher, respectively, in 6 week and 18 month old $\mathrm{mdx}$ plasma compared with age-matched C57 plasma (Figure 3C). Treadmill exercise increased irreversible albumin thiol oxidation 1.5 fold in 6 week old mdx plasma (Figure 3C). In C57 plasma, irreversible albumin thiol oxidation decreases $60 \%$ from 23 day to 6 weeks, and it increases 2.7 fold from 6 to 12 weeks (Figure 3C). Age had no effect on irreversible albumin thiol oxidation in mdx plasma (Figure 3C).

Protein carbonylation was 2 fold higher in 18 month old mdx plasma compared with age-matched C57 muscle (Figure 3D). In C57 plasma, no differences were observed for protein carbonylation across the age groups, however in $\mathrm{mdx}$ mice, protein carbonylation was approximately 2 fold higher in 18 month plasma compared to all other age groups.

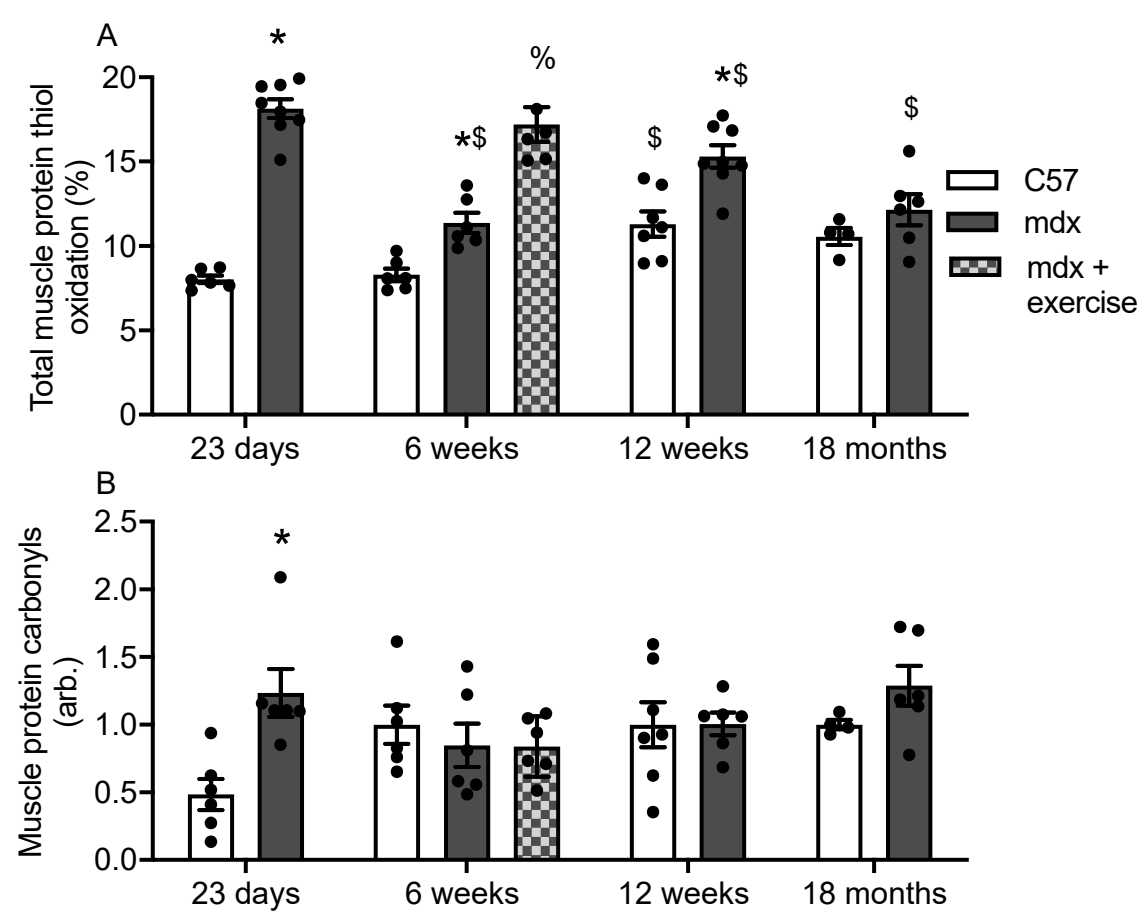

Figure 2. Protein thiol oxidation (A) and protein carbonylation (B) in C57 and $\mathrm{mdx}$ muscle at various time points. ${ }^{*}=$ significantly $(p<0.05)$ different to age matched control. $\%=$ significant $(p<0.05)$ different to unexercised 6 week old $\mathrm{mdx} . \$=$ significantly $(p<0.05)$ different to previous age group of same strain. Bars represent mean \pm SEM and $n=5-8$ per group.

\subsection{Creatine Kinase (CK) in Plasma of C57 and Mdx Mice}

As a measure of $\mathrm{mdx}$ muscle dystropathology, plasma CK levels were quantified in all groups. Plasma CK was higher in 23 day, 6 week, 12 week and 18 month old mdx plasma compared with age-matched C57 plasma (Figure 4). Treadmill exercise increased CK levels 
5 fold in 6 week old mdx plasma. Age had no effect on CK levels in C57 plasma; in mdx plasma, CK decreased 60\% from 23 days to 6 weeks (Figure 4).
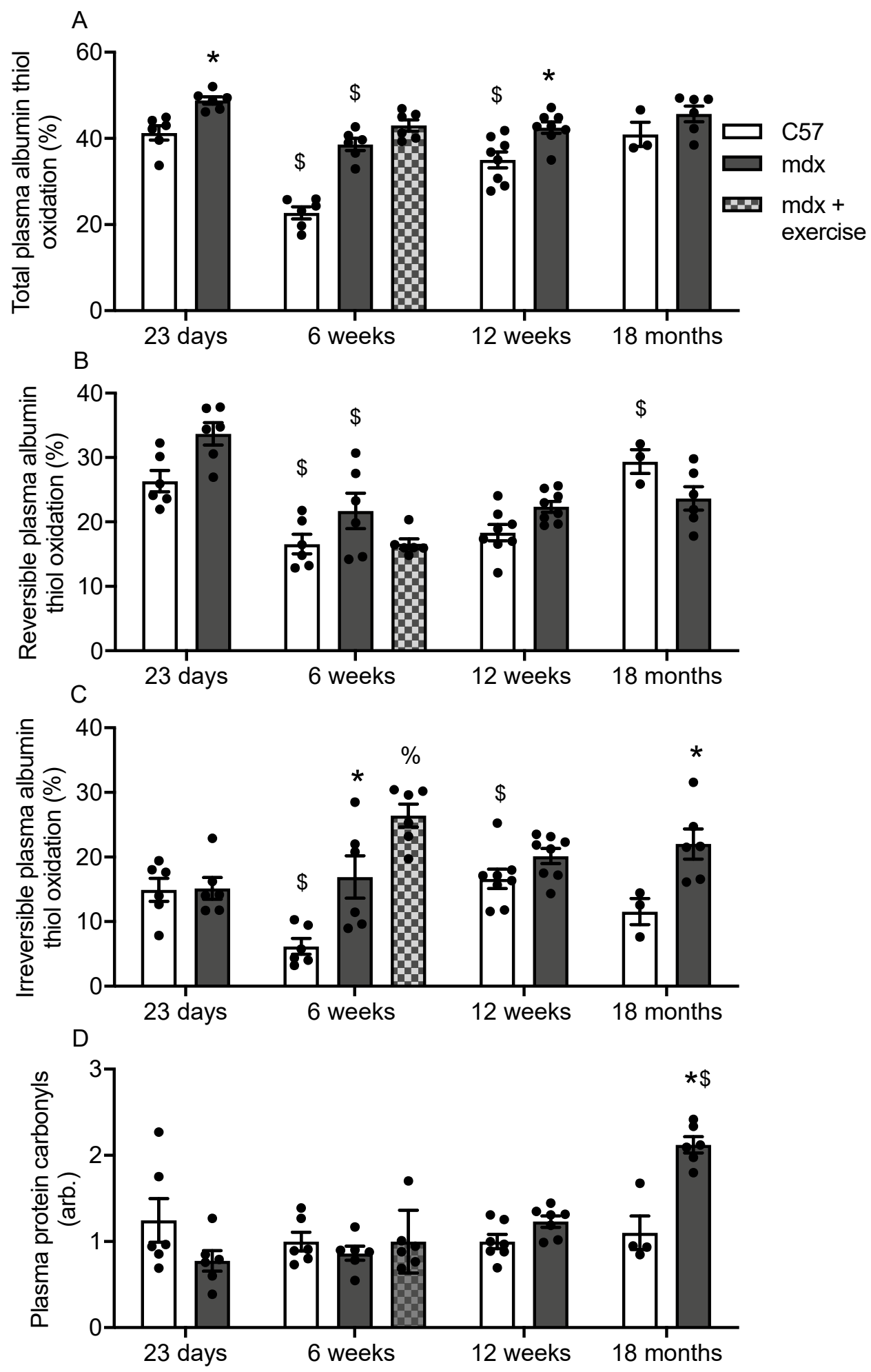

Figure 3. Total albumin thiol oxidation (A), reversible albumin thiol oxidation (B), irreversible albumin thiol oxidation (C) and protein carbonylation (D) in C57 and mdx plasma at various time points. ${ }^{*}=$ significantly $(p<0.05)$ different to age matched control. $\%=$ significant $(p<0.05)$ different to unexercised 6 week old mdx. $\$=$ significantly $(p<0.05)$ different to previous age group of same strain. Bars represent mean \pm SEM and $n=5-8$ per group. 


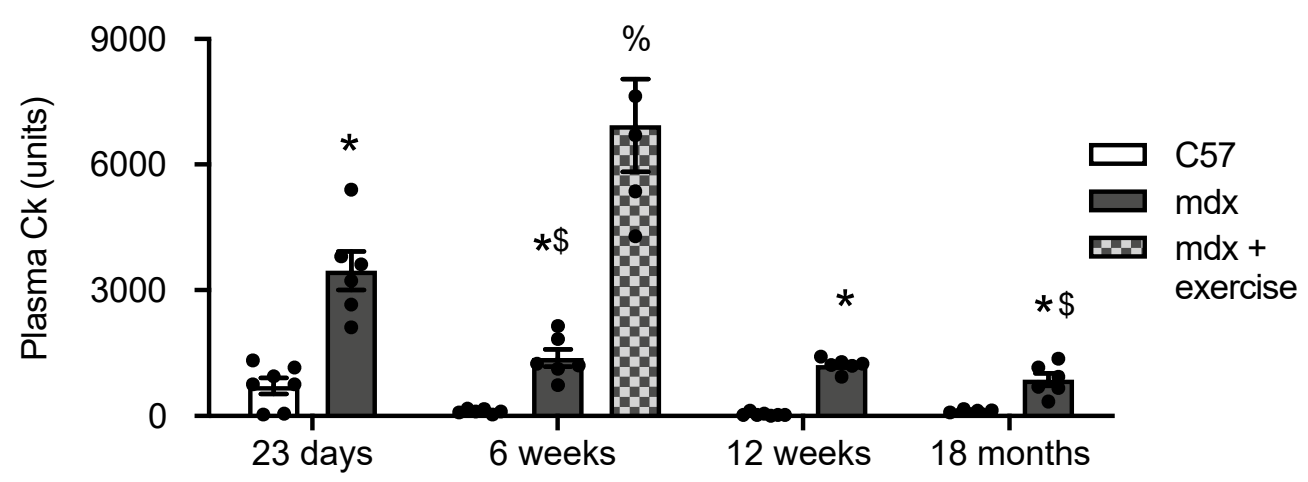

Figure 4. Creatine Kinase $(\mathrm{CK})$ in $\mathrm{C} 57$ and $\mathrm{mdx}$ plasma at various time points. ${ }^{*}=$ significantly $(p<0.05)$ different to age matched control. $\%=$ significant $(p<0.05)$ different to unexercised 6 week old mdx. $\$=$ significantly $(p<0.05)$ different to previous age group of same strain. Bars represent mean \pm SEM and $n=5-8$ per group.

\subsection{Correlation Analysis}

To determine if plasma levels of albumin thiol oxidation and carbonylation reflect muscle tissue state, correlation analysis was performed, and we also compared plasma levels of albumin thiol oxidation and carbonylation to levels of plasma CK (the classic readout of dystropathology.

A positive relationship was observed between muscle protein thiol oxidation and total and irreversible plasma albumin thiol oxidation (Table 1) and also between plasma CK and total and irreversible plasma albumin thiol oxidation (Table 1). There was no relationship between muscle carbonylation and plasma CK nor plasma protein carbonylation (Table 1).

Table 1. Correlation between muscle and plasma protein thiol oxidation (PTO) and protein carbonylation (prot. carb.) makers, and between plasma CK and plasma protein oxidation markers in C57 and mdx mice. $N=54$ and asterisks represent significant correlation of $p<0.05$.

\begin{tabular}{cccc}
\hline Indices 1 & Indices 1 & $r$ & $p$ \\
\hline Muscle PTO & Plasma total PTO & 0.5 & $<0.0001^{*}$ \\
Muscle PTO & Plasma revers. PTO & 0.15 & 0.3303 \\
Muscle PTO & Plasma irrevers. PTO & 0.5 & $0.0002^{*}$ \\
Muscle prot. carb. & Plasma prot. carb. & 0.05 & 0.7 \\
Plasma CK & Plasma total PTO & 0.4 & $0.007^{*}$ \\
Plasma CK & Plasma revers. PTO & 0.04 & 0.8 \\
Plasma CK & Plasma irrevers. PTO & 0.4 & $0.004^{*}$ \\
Plasma CK & Plasma prot. carb. & -0.1 & 0.3 \\
\hline
\end{tabular}

\subsection{Albumin Thiol Oxidation in Plasma of Taurine Treated Mdx Mice}

To assess the use of plasma albumin thiol oxidation as a readout of drug efficacy, muscle and plasma thiol oxidation was measured in young mdx mice treated with taurine for 9 days. Firstly, to demonstrate that taurine was effective at decreasing dystropathology in 23 day old $\mathrm{mdx}$ mice, plasma CK was measured; taurine treatment decreased CK levels by $30 \%$ (Figure $5 \mathrm{~A}$ ). Taurine treatment also decreased protein thiol oxidation by $20 \%$ in $\mathrm{mdx}$ muscle (Figure $5 \mathrm{~B}$ ) and decreased total albumin thiol oxidation by $17 \%$ (Figure $5 \mathrm{C}$ ) and reversible albumin thiol oxidation by $19 \%$ in mdx plasma (Figure 5D). Taurine treatment had no effect on irreversible albumin thiol oxidation in mdx plasma at 23 days. 

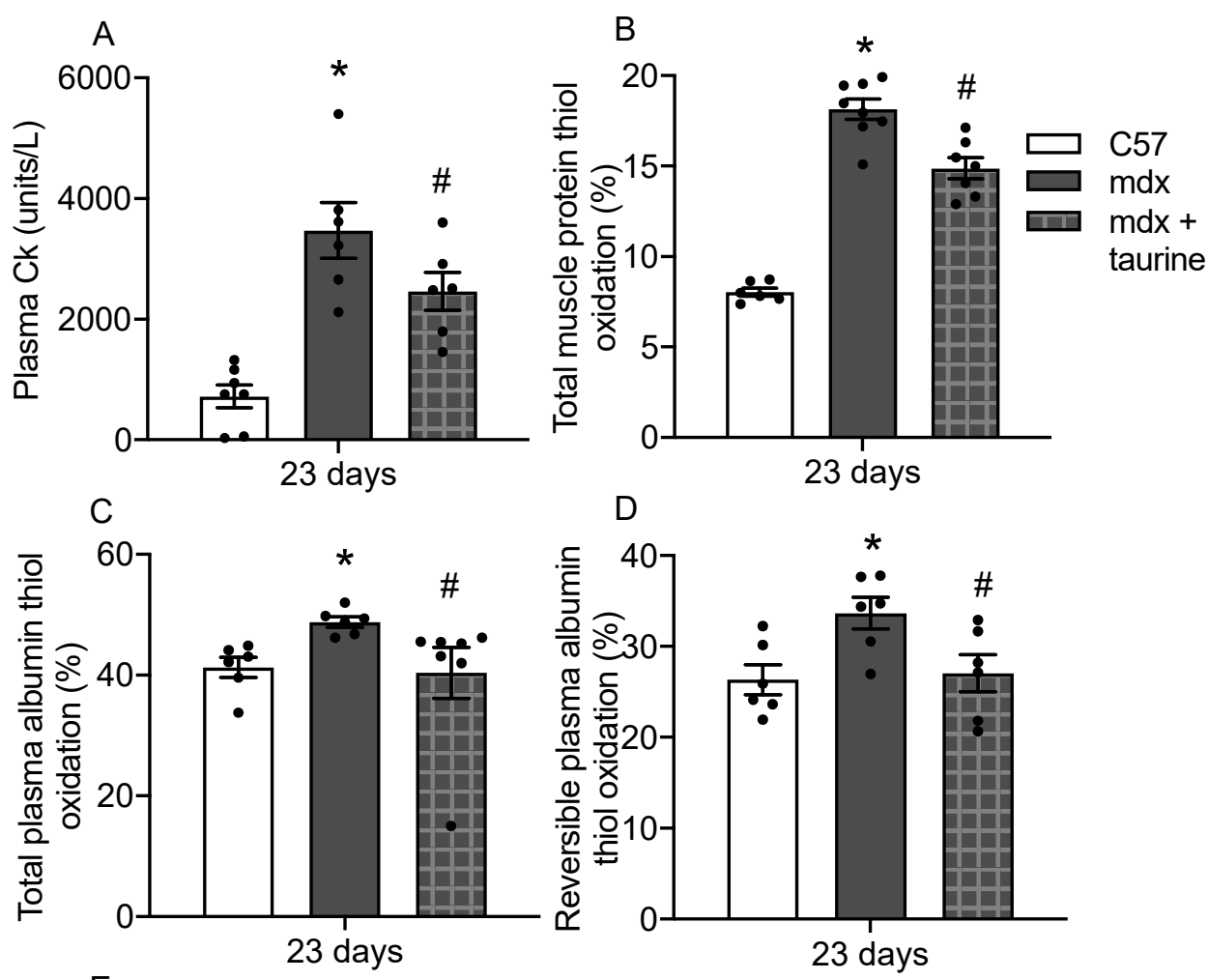

$E$

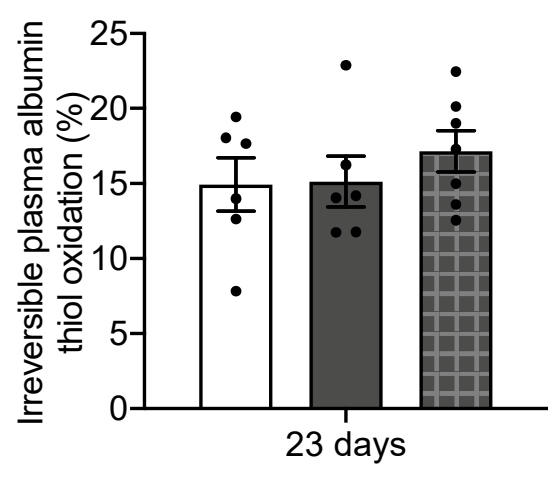

Figure 5. Plasma CK (A), total muscle protein thiol oxidation (B), total plasma albumin thiol oxidation (C), reversible plasma albumin thiol oxidation (D), irreversible plasma albumin thiol oxidation (E) and protein carbonylation (D) in C57 and mdx plasma at various time points. ${ }^{*}=$ significantly $(p<0.05)$ different to age matched control. $\#=$ significant $(p<0.05)$ different to untreated mdx. Bars represent mean \pm SEM and $n=5-8$ per group.

\section{Discussion}

A key finding of this study is that albumin Cys34 thiol oxidation in plasma correlates with protein thiol oxidation in dystrophic muscle, with both being increased in mdx mice compared with normal C57 mice at multiple time points across the progression of the disease. Our data suggest that plasma albumin oxidation is a more sensitive indicator of oxidative stress in mdx muscle compared with the commonly used biomarker protein carbonylation. We also show that both plasma albumin thiol oxidation and muscle protein thiol oxidation are sensitive to two modulators of dystropathology, treadmill exercise and taurine treatment that, respectively, increase and decrease myonecrosis. Additionally, plasma albumin thiol oxidation correlates with plasma CK levels, a biomarker of dystropathology (myonecrosis).

We measured plasma albumin thiol oxidation at various time points across the lie span of the mdx mice- at 23 days (during the acute phase of myonecrosis), 6 weeks (after the initial phase of myonecrosis has reduced and stabilised, and is approaching adult 
levels), 12 weeks (stable adult levels of myonecrosis) and 18 months (extensive fibrosis is evident) $[47-50,59]$. These ages were chosen on the basis of changes in muscle pathology. The ages also include many (but not all) ages that are used experimentally. We show that increased plasma albumin thiol oxidation occurs in mdx mice at all time points. Furthermore, there were significant correlations between plasma albumin thiol oxidation with protein thiol oxidation in $\mathrm{mdx}$ muscle. These data provide the first experimental evidence that plasma thiol oxidation changes reflect the levels of protein oxidation in muscle. Previous research has shown increased oxidation of serum Cys34 albumin in acuteon-chronic liver failure [32], liver cirrhosis [42], chronic renal failure [43], and diabetes mellitus [44], but these studies did not examine whether there were concomitant changes in tissue. We also generated novel data of oxidative state of plasma albumin Cys34 albumin oxidation in healthy mice, total albumin oxidation was between 20 and $40 \%$, reversible was between 15 and $30 \%$ and irreversible oxidation was between $6-16 \%$. In comparison, for healthy adult human serum, total Cys 34 albumin oxidation is $20-30 \%$, with irreversible oxidation at $2-5 \%$ and reversible oxidation at $20-30 \%$ (reviewed in [34]).

In adult $\mathrm{mdx}$ mice, exercise is routinely used to increase dystrophic myofibre damage [51-54]; and for this reason we included a study to examine the impact of exercise on albumin thiol oxidation. In the current study, treadmill exercise increased plasma CK and muscle protein thiol oxidation. While no changes in total and reversible albumin thiol oxidation were observed, treadmill exercise of $\mathrm{mdx}$ mice increased irreversible albumin thiol oxidation in plasma. Irreversible thiol oxidation includes the formation of sulfinic $\left(-\mathrm{SO}_{2} \mathrm{H}\right)$ and sulfonic acid $\left(-\mathrm{SO}_{3} \mathrm{H}\right)$ forms [38-40], and is generally associated with a loss of function, and degradation of the protein [74].

Our results show that protein carbonylation, a consequence of irreversible oxidative modification of proteins which yields carbonyl groups such as ketones and aldehydes [75] and reviewed in [76,77], occurs primarily on albumin in plasma. This observation is consistent with earlier studies that show plasma albumin is the major carbonylated protein in chronic kidney disease and hemodialysis patients $[78,79]$. However, we show no strain specific difference in albumin carbonylation when comparing $\mathrm{mdx}$ and C57 plasma, apart from at 18 months. In contrast, in mdx muscle protein carbonylation is elevated at 23 days compared to C57 muscle, while there were no difference between $\mathrm{mdx}$ and C57 at the other age groups. Moreover, we find no correlation between plasma albumin carbonylation and muscle protein carbonylation. Some animal studies have investigated the relationship between protein carbonylation in plasma and muscle tissue. For example, in rats, protein carbonyls increased in both muscle and plasma after exercise [80]; although another study showed no change in protein carbonylation after acute exercise in rat brain, liver, heart, and skeletal muscle [81]. Moreover, a third study in rats reported that measuring serum protein carbonylation was not a useful indicator of the degree of tissue protein oxidative damage [26]. Taken together, our work, and previous studies indicate that plasma protein carbonylation cannot be assumed to reflect changes in muscle protein oxidation.

To investigate the use of plasma albumin thiol oxidation as a readout dystropathology, young $\mathrm{mdx}$ mice were treated with the drug taurine. As per our previous studies, taurine treatment reduced mdx myofibre damage, as measured by plasma CK [66,69,82]. Plasma CK reflects increased sarcolemmal fragility (reviewed in $[3,64]$, which has long been linked to muscle damage in muscular dystrophy $[83,84]$. In the current study, we show that total and reversible plasma Cys34 albumin thiol oxidation were also decreased in response to taurine treatment of mdx mice, as was muscle protein thiol oxidation. Although irreversible albumin oxidation did not change with taurine treatment, data indicate that plasma total and reversible albumin thiol oxidation reflect both muscle thiol oxidation and damage.

These data also suggest that the mechanism by which taurine may be protecting dystrophic muscle is by decreasing oxidative stress; we have previously proposed that taurine protects dystrophic muscle through its interaction with the neutrophil/HOCl pathway [18]. Neutrophils secrete $\mathrm{HOCl}$, which is a potent ROS that targets proteins by reacting extremely rapidly with thiols and by causing oxidative damage [85]. Taurine can 
scavenge taurine via the formation of taurine chloramine, a molecule that has additional anti-inflammatory properties (reviewed in [86]). However, further investigation is required to establish the role of $\mathrm{HOCl}$ in dystropathology and albumin oxidation.

\section{Conclusions}

In summary, our data show that plasma Cys34 albumin thiol oxidation is a useful blood biomarker of oxidative stress in mdx mice, and that changes in such thiol oxidation in plasma more closely reflect changes in protein thiol oxidation in dystrophic muscle, than the commonly used biomarker protein carbonylation. As discussed in a recent review [64] a range of studies are required to demonstrate that such candidate blood biomarkers for DMD are robust, and relate to the extent of myonecrosis in animal models of DMD, as demonstrated here for in Cys34 albumin in response to exercise, and in taurine treated young mdx mice. In order to further validate the use of Cys34 albumin thiol oxidation as a potential blood biomarker for tracking oxidative stress in DMD, it is desirable to do such measurements in other mammalian models of DMD such as dystrophic rats and dogs and to check the pre-clinical response of this new blood biomarker to beneficial treatments that protect dystrophic muscles from myonecrosis [64], plus to do clinical analyses of blood from a range of DMD patients and control human subjects. The data presented here suggest that albumin Cys34 thiol oxidation has the potential to be a useful robust blood biomarker of dystropathology and may be used to efficiently evaluate and advance the development of therapies for DMD.

Supplementary Materials: The following are available online at https:/ / www.mdpi.com/article/10 $.3390 /$ antiox10081241/s1.

Author Contributions: All authors (B.A.A.-M., M.D.G., P.G.A. and J.R.T.) designed the research. B.A.A.-M. performed the analysis. J.R.T. wrote the manuscript with assistance from other authors. All authors (B.A.A.-M., M.D.G., P.G.A. and J.R.T.) reviewed the manuscript. All authors have read and agreed to the published version of the manuscript.

Funding: This research was supported by funding from Duchenne UK, Save Our Sons Duchenne Foundation (Australia), Muscular Dystrophy Western Australia and the French Muscular Dystrophy Association (AFM-Téléthon), plus PhD funding from the Higher Committee for Education Development in Iraq (B.A.A.-M.).

Institutional Review Board Statement: The study was conducted according to the guidelines of the National Health and Medical Research Council Code of practice for the care and use of animals for scientific purposes (2004), and the Animal Welfare act of Western Australia (2002), and were approved by the Animal Ethics committee at the University of Western Australia under approval number RA/3/100/1436.

Informed Consent Statement: Not applicable.

Data Availability Statement: Data is contained within the article and Supplementary Materials.

Conflicts of Interest: The authors declare no conflict of interest.

\section{References}

1. Bushby, K.; Finkel, R.; Birnkrant, D.J.; Case, L.E.; Clemens, P.R.; Cripe, L.; Kaul, A.; Kinnett, K.; McDonald, C.; Pandya, S.; et al. Diagnosis and management of Duchenne muscular dystrophy, part 1: Diagnosis, and pharmacological and psychosocial management. Lancet Neurol. 2010, 9, 77-93. [CrossRef]

2. Duan, D.; Goemans, N.; Takeda, S.; Mercuri, E.; Aartsma-Rus, A. Duchenne muscular dystrophy. Nat. Rev. Dis. Primers 2021, 7, 13. [CrossRef] [PubMed]

3. Grounds, M.D. Two-tiered hypotheses for Duchenne muscular dystrophy. Cell. Mol. Life Sci. 2008, 65, 1621-1625. [CrossRef]

4. Kharraz, Y.; Guerra, J.; Pessina, P.; Serrano, A.L.; Munoz-Canoves, P. Understanding the process of fibrosis in Duchenne muscular dystrophy. Biomed. Res. Int. 2014, 2014, 965631. [CrossRef]

5. Falzarano, M.S.; Scotton, C.; Passarelli, C.; Ferlini, A. Duchenne Muscular Dystrophy: From Diagnosis to Therapy. Molecules 2015, 20, 18168-18184. [CrossRef]

6. Allen, D.G.; Whitehead, N.P.; Froehner, S.C. Absence of Dystrophin Disrupts Skeletal Muscle Signaling: Roles of Ca ${ }^{2+}$, Reactive Oxygen Species, and Nitric Oxide in the Development of Muscular Dystrophy. Physiol. Rev. 2016, 96, 253-305. [CrossRef] 
7. Arthur, P.G.; Grounds, M.D.; Shavlakadze, T. Oxidative stress as a therapeutic target during muscle wasting: Considering the complex interactions. Curr. Opin. Clin. Nutr. Metab. Care 2008, 11, 408-416. [CrossRef] [PubMed]

8. Terrill, J.R.; Radley-Crabb, H.G.; Iwasaki, T.; Lemckert, F.A.; Arthur, P.G.; Grounds, M.D. Oxidative stress and pathology in muscular dystrophies: Focus on protein thiol oxidation and dysferlinopathies. FEBS J. 2013, 280, 4149-4164. [CrossRef]

9. Kourakis, S.; Timpani, C.A.; de Haan, J.B.; Gueven, N.; Fischer, D.; Rybalka, E. Targeting Nrf2 for the treatment of Duchenne Muscular Dystrophy. Redox Biol. 2021, 38, 101803. [CrossRef]

10. El-Shafey, A.F.; Armstrong, A.E.; Terrill, J.R.; Grounds, M.D.; Arthur, P.G. Screening for increased protein thiol oxidation in oxidatively stressed muscle tissue. Free Radic. Res. 2011, 45, 991-999. [CrossRef]

11. Turell, L.; Radi, R.; Alvarez, B. The thiol pool in human plasma: The central contribution of albumin to redox processes. Free Radic. Biol. Med. 2013, 65, 244-253. [CrossRef] [PubMed]

12. Tan, P.L.; Shavlakadze, T.; Grounds, M.D.; Arthur, P.G. Differential thiol oxidation of the signaling proteins Akt, PTEN or PP2A determines whether Akt phosphorylation is enhanced or inhibited by oxidative stress in C2C12 myotubes derived from skeletal muscle. Int. J. Biochem. Cell Biol. 2015, 62, 72-79. [CrossRef]

13. Armstrong, A.E.; Zerbes, R.; Fournier, P.A.; Arthur, P.G. A fluorescent dual labeling technique for the quantitative measurement of reduced and oxidized protein thiols in tissue samples. Free Radic. Biol. Med. 2010, 50, 510-517. [CrossRef]

14. Iwasaki, T.; Terrill, J.; Shavlakadze, T.; Grounds, M.D.; Arthur, P.G. Visualizing and quantifying oxidized protein thiols in tissue sections: A comparison of dystrophic $\mathrm{mdx}$ and normal skeletal mouse muscles. Free Radic. Biol. Med. 2013, 65, 1408-1416. [CrossRef]

15. Maciazek-Jurczyk, M.; Sulkowska, A. Spectroscopic analysis of the impact of oxidative stress on the structure of human serum albumin (HSA) in terms of its binding properties. Spectrochim. Acta A Mol. Biomol. Spectrosc. 2015, 136 Pt B, 265-282. [CrossRef]

16. Terrill, J.R.; Radley-Crabb, H.G.; Grounds, M.D.; Arthur, P.G. N-Acetylcysteine treatment of dystrophic mdx mice results in protein thiol modifications and inhibition of exercise induced myofibre necrosis. Neuromuscul. Disord. 2012, 22, 427-434. [CrossRef]

17. Radley-Crabb, H.G.; Terrill, J.R.; Shavlakadze, T.; Tonkin, J.; Arthur, P.G.; Grounds, M.D. A single 30 min treadmill exercise session is suitable for 'proof-of concept studies' in adult mdx mice: A comparison of the early consequences of two different treadmill protocols. Neuromuscul. Disord. 2012, 22, 170-182. [CrossRef] [PubMed]

18. Terrill, J.R.; Duong, M.N.; Turner, R.; Le Guiner, C.; Boyatzis, A.; Kettle, A.J.; Grounds, M.D.; Arthur, P.G. Levels of inflammation and oxidative stress, and a role for taurine in dystropathology of the Golden Retriever Muscular Dystrophy dog model for Duchenne Muscular Dystrophy. Redox Biol. 2016, 9, 276-286. [CrossRef]

19. Terrill, J.R.; Boyatzis, A.; Grounds, M.D.; Arthur, P.G. Treatment with the cysteine precursor 1-2-oxothiazolidine-4-carboxylate (OTC) implicates taurine deficiency in severity of dystropathology in mdx mice. Int. J. Biochem. Cell Biol. 2013, 45, $2097-2108$. [CrossRef]

20. Dalle-Donne, I.; Aldini, G.; Carini, M.; Colombo, R.; Rossi, R.; Milzani, A. Protein carbonylation, cellular dysfunction, and disease progression. J. Cell. Mol. Med. 2006, 10, 389-406. [CrossRef] [PubMed]

21. Valko, M.; Leibfritz, D.; Moncol, J.; Cronin, M.T.; Mazur, M.; Telser, J. Free radicals and antioxidants in normal physiological functions and human disease. Int. J. Biochem. Cell Biol. 2007, 39, 44-84. [CrossRef] [PubMed]

22. Frijhoff, J.; Winyard, P.G.; Zarkovic, N.; Davies, S.S.; Stocker, R.; Cheng, D.; Knight, A.R.; Taylor, E.L.; Oettrich, J.; Ruskovska, T.; et al. Clinical Relevance of Biomarkers of Oxidative Stress. Antioxid. Redox. Signal. 2015, 23, 1144-1170. [CrossRef] [PubMed]

23. Hondur, G.; Göktas, E.; Yang, X.; Al-Aswad, L.; Auran, J.D.; Blumberg, D.M.; Cioffi, G.A.; Liebmann, J.M.; Suh, L.H.; Trief, D.; et al. Oxidative Stress-Related Molecular Biomarker Candidates for Glaucoma. Investig. Ophthalmol. Vis. Sci. 2017, 58, 4078-4088. [CrossRef]

24. Milne, G.L.; Yin, H.; Hardy, K.D.; Davies, S.S.; Roberts, L.J., 2nd. Isoprostane generation and function. Chem. Rev. 2011, 111, 5973-5996. [CrossRef] [PubMed]

25. Spanidis, Y.; Priftis, A.; Stagos, D.; Stravodimos, G.A.; Leonidas, D.D.; Spandidos, D.A.; Tsatsakis, A.M.; Kouretas, D. Oxidation of human serum albumin exhibits inter-individual variability after an ultra-marathon mountain race. Exp. Ther. Med. 2017, 13, 2382-2390. [CrossRef]

26. Argüelles, S.; García, S.; Maldonado, M.; Machado, A.; Ayala, A. Do the serum oxidative stress biomarkers provide a reasonable index of the general oxidative stress status? Biochim. Biophys. Acta 2004, 1674, 251-259. [CrossRef] [PubMed]

27. Dumlu, E.G.; Tokaç, M.; Bozkurt, B.; Yildirim, M.B.; Ergin, M.; Yalçin, A.; Kiliç, M. Correlation between the serum and tissue levels of oxidative stress markers and the extent of inflammation in acute appendicitis. Clinics 2014, 69, 677-682. [CrossRef]

28. Veskoukis, A.S.; Nikolaidis, M.G.; Kyparos, A.; Kouretas, D. Blood reflects tissue oxidative stress depending on biomarker and tissue studied. Free Radic. Biol. Med. 2009, 47, 1371-1374. [CrossRef]

29. Margaritelis, N.V.; Cobley, J.N.; Paschalis, V.; Veskoukis, A.S.; Theodorou, A.A.; Kyparos, A.; Nikolaidis, M.G. Going retro: Oxidative stress biomarkers in modern redox biology. Free Radic. Biol. Med. 2016, 98, 2-12. [CrossRef] [PubMed]

30. Margaritelis, N.V.; Veskoukis, A.S.; Paschalis, V.; Vrabas, I.S.; Dipla, K.; Zafeiridis, A.; Kyparos, A.; Nikolaidis, M.G. Blood reflects tissue oxidative stress: A systematic review. Biomarkers 2015, 20, 97-108. [CrossRef]

31. Fanali, G.; Di Masi, A.; Trezza, V.; Marino, M.; Fasano, M.; Ascenzi, P. Human serum albumin: From bench to bedside. Mol. Asp. Med. 2012, 33, 209-290. [CrossRef] [PubMed] 
32. Oettl, K.; Birner-Gruenberger, R.; Spindelboeck, W.; Stueger, H.P.; Dorn, L.; Stadlbauer, V.; Putz-Bankuti, C.; Krisper, P.; Graziadei, I.; Vogel, W.; et al. Oxidative albumin damage in chronic liver failure: Relation to albumin binding capacity, liver dysfunction and survival. J. Hepatol. 2013, 59, 978-983. [CrossRef]

33. Di Giuseppe, D.; Ulivelli, M.; Bartalini, S.; Battistini, S.; Cerase, A.; Passero, S.; Summa, D.; Frosali, S.; Priora, R.; Margaritis, A.; et al. Regulation of redox forms of plasma thiols by albumin in multiple sclerosis after fasting and methionine loading test. Amino Acids 2010, 38, 1461-1471. [CrossRef]

34. Oettl, K.; Marsche, G. Redox state of human serum albumin in terms of cysteine-34 in health and disease. Methods Enzymol. 2010, 474, 181-195.

35. Belinskaia, D.A.; Voronina, P.A.; Batalova, A.A.; Goncharov, N.V. Serum Albumin. Encyclopedia 2021, 1, 9. [CrossRef]

36. Medina-Navarro, R.; Corona-Candelas, I.; Barajas-González, S.; Díaz-Flores, M.; Durán-Reyes, G. Albumin antioxidant response to stress in diabetic nephropathy progression. PLoS ONE 2014, 9, e106490. [CrossRef] [PubMed]

37. Candiano, G.; Petretto, A.; Bruschi, M.; Santucci, L.; Dimuccio, V.; Prunotto, M.; Gusmano, R.; Urbani, A.; Ghiggeri, G.M. The oxido-redox potential of albumin methodological approach and relevance to human diseases. J. Proteom. 2009, 73, 188-195. [CrossRef] [PubMed]

38. Watanabe, H.; Imafuku, T.; Otagiri, M.; Maruyama, T. Clinical Implications Associated With the Posttranslational ModificationInduced Functional Impairment of Albumin in Oxidative Stress-Related Diseases. J. Pharm. Sci. 2017, 106, 2195-2203. [CrossRef]

39. Bocedi, A.; Cattani, G.; Stella, L.; Massoud, R.; Ricci, G. Thiol disulfide exchange reactions in human serum albumin: The apparent paradox of the redox transitions of Cys 34 . FEBS J. 2018, 285, 3225-3237. [CrossRef] [PubMed]

40. Bonanata, J.; Turell, L.; Antmann, L.; Ferrer-Sueta, G.; Botasini, S.; Méndez, E.; Alvarez, B.; Coitiño, E.L. The thiol of human serum albumin: Acidity, microenvironment and mechanistic insights on its oxidation to sulfenic acid. Free Radic. Biol. Med. 2017, 108, 952-962. [CrossRef]

41. Colombo, G.; Clerici, M.; Giustarini, D.; Rossi, R.; Milzani, A.; Dalle-Donne, I. Redox albuminomics: Oxidized albumin in human diseases. Antioxid. Redox. Signal. 2012, 17, 1515-1527. [CrossRef] [PubMed]

42. Rasheed, Z.; Ali, R. Reactive oxygen species damaged human serum albumin in patients with type 1 diabetes mellitus: Biochemical and immunological studies. Life Sci. 2006, 79, 2320-2328. [CrossRef]

43. Terawaki, H.; Yoshimura, K.; Hasegawa, T.; Matsuyama, Y.; Negawa, T.; Yamada, K.; Matsushima, M.; Nakayama, M.; Hosoya, T.; Era, S. Oxidative stress is enhanced in correlation with renal dysfunction: Examination with the redox state of albumin. Kidney Int. 2004, 66, 1988-1993. [CrossRef]

44. Oettl, K.; Reibnegger, G.; Schmut, O. The redox state of human serum albumin in eye diseases with and without complications. Acta Ophthalmol. 2011, 89, e174-e179. [CrossRef] [PubMed]

45. Nasif, W.A.; Mukhtar, M.H.; El-Emshaty, H.M.; Alwazna, A.H. Redox State of Human Serum Albumin and Inflammatory Biomarkers in Hemodialysis Patients with Secondary Hyperparathyroidism During Oral Calcitriol Supplementation for Vitamin D. Open J. Med. Chem. 2018, 12, 98-110. [CrossRef] [PubMed]

46. Lim, Z.X.; Duong, M.N.; Boyatzis, A.E.; Golden, E.; Vrielink, A.; Fournier, P.A.; Arthur, P.G. Oxidation of cysteine 34 of plasma albumin as a biomarker of oxidative stress. Free Radic. Res. 2020, 54, 91-103. [CrossRef]

47. McGeachie, J.K.; Grounds, M.D.; Partridge, T.A.; Morgan, J.E. Age-related changes in replication of myogenic cells in mdx mice: Quantitative autoradiographic studies. J. Neurol. Sci. 1993, 119, 169-179. [CrossRef]

48. Grounds, M.D.; Torrisi, J. Anti-TNF alpha (Remicade (R)) therapy protects dystrophic skeletal muscle from necrosis. FASEB J. 2004, 18, 676-682. [CrossRef] [PubMed]

49. Radley, H.G.; Grounds, M.D. Cromolyn administration (to block mast cell degranulation) reduces necrosis of dystrophic muscle in mdx mice. Neurobiol. Dis. 2006, 23, 387-397. [CrossRef]

50. Radley, H.G.; Davies, M.J.; Grounds, M.D. Reduced muscle necrosis and long-term benefits in dystrophic mdx mice after cV1q (blockade of TNF) treatment. Neuromuscul. Disord. 2008, 18, 227-238. [CrossRef]

51. Brussee, V.; Tardif, F.; Tremblay, J.P. Muscle fibers of mdx mice are more vulnerable to exercise than those of normal mice. Neuromuscul. Disord. 1997, 7, 487-492. [CrossRef]

52. Vilquin, J.T.; Brussee, V.; Asselin, I.; Kinoshita, I.; Gingras, M.; Tremblay, J.P. Evidence of mdx mouse skeletal muscle fragility in vivo by eccentric running exercise. Muscle Nerve 1998, 21, 567-576. [CrossRef]

53. De Luca, A.; Pierno, S.; Liantonio, A.; Cetrone, M.; Camerino, C.; Fraysse, B.; Mirabella, M.; Servidei, S.; Ruegg, U.T.; Conte Camerino, D. Enhanced dystrophic progression in $\mathrm{mdx}$ mice by exercise and beneficial effects of taurine and insulin-like growth factor-1. J. Pharmacol. Exp. Ther. 2003, 304, 453-463. [CrossRef] [PubMed]

54. Okano, T.; Yoshida, K.; Nakamura, A.; Sasazawa, F.; Oide, T.; Takeda, S.; Ikeda, S. Chronic exercise accelerates the degenerationregeneration cycle and downregulates insulin-like growth factor-1 in muscle of mdx mice. Muscle Nerve 2005, 32, 191-199. [CrossRef] [PubMed]

55. Archer, J.D.; Vargas, C.C.; Anderson, J.E. Persistent and improved functional gain in mdx dystrophic mice after treatment with L-arginine and deflazacort. FASEB J. 2006, 20, 738-740. [CrossRef] [PubMed]

56. Payne, E.T.; Yasuda, N.; Bourgeois, J.M.; Devries, M.C.; Rodriguez, M.C.; Yousuf, J.; Tarnopolsky, M.A. Nutritional therapy improves function and complements corticosteroid intervention in mdx mice. Muscle Nerve 2006, 33, 66-77. [CrossRef] [PubMed] 
57. Burdi, R.; Rolland, J.F.; Fraysse, B.; Litvinova, K.; Cozzoli, A.; Giannuzzi, V.; Liantonio, A.; Camerino, G.M.; Sblendorio, V.; Capogrosso, R.F. Multiple pathological events in exercised dystrophic mdx mice are targeted by pentoxifylline: Outcome of a large array of in vivo and ex vivo tests. J. Appl. Physiol. 2009, 106, 1311-1324. [CrossRef]

58. Frinchi, M.; Morici, G.; Mudó, G.; Bonsignore, M.R.; Di Liberto, V. Beneficial Role of Exercise in the Modulation of mdx Muscle Plastic Remodeling and Oxidative Stress. Antioxidants 2021, 10, 558. [CrossRef]

59. Pastoret, C.; Sebille, A. Mdx mice show progressive weakness and muscle deterioration with age. J. Neurol. Sci. 1995, 129, 97-105. [CrossRef]

60. Chamberlain, J.S.; Metzger, J.; Reyes, M.; Townsend, D.; Faulkner, J.A. Dystrophin-deficient mdx mice display a reduced life span and are susceptible to spontaneous rhabdomyosarcoma. FASEB J. 2007, 21, 2195-2204. [CrossRef]

61. Lefaucheur, J.P.; Pastoret, C.; Sebille, A. Phenotype of dystrophinopathy in old mdx mice. Anat. Rec. 1995, 242, 70-76. [CrossRef] [PubMed]

62. Ziemba, M.; Barkhouse, M.; Uaesoontrachoon, K.; Giri, M.; Hathout, Y.; Dang, U.J.; Gordish-Dressman, H.; Nagaraju, K.; Hoffman, E.P. Biomarker-focused multi-drug combination therapy and repurposing trial in mdx mice. PLoS ONE 2021, 16, e0246507. [CrossRef]

63. Dang, U.J.; Ziemba, M.; Clemens, P.R.; Hathout, Y.; Conklin, L.S.; Hoffman, E.P. Serum biomarkers associated with baseline clinical severity in young steroid-naïve Duchenne muscular dystrophy boys. Hum. Mol. Genet. 2020, 29, 2481-2495. [CrossRef] [PubMed]

64. Grounds, M.D.; Terrill, J.R.; Al-Mshhdani, B.A.; Duong, M.N.; Radley-Crabb, H.G.; Arthur, P.G. Biomarkers for Duchenne muscular dystrophy: Myonecrosis, inflammation and oxidative stress. Dis. Model. Mech. 2020, 13, dmm043638. [CrossRef]

65. Dalle-Donne, I.; Giustarini, D.; Colombo, R.; Rossi, R.; Milzani, A. Protein carbonylation in human diseases. Trends Mol. Med. 2003, 9, 169-176. [CrossRef]

66. Terrill, J.R.; Pinniger, G.J.; Graves, J.A.; Grounds, M.D.; Arthur, P.G. Increasing taurine intake and taurine synthesis improves skeletal muscle function in the mdx mouse model for Duchenne muscular dystrophy. J. Physiol. 2016, 594, 3095-3110. [CrossRef]

67. Terrill, J.R.; Pinniger, G.J.; Nair, K.V.; Grounds, M.D.; Arthur, P.G. Beneficial effects of high dose taurine treatment in juvenile dystrophic mdx mice are offset by growth restriction. PLoS ONE 2017, 12, e0187317. [CrossRef] [PubMed]

68. Terrill, J.R.; Webb, S.M.; Arthur, P.G.; Hackett, M.J. Investigation of the effect of taurine supplementation on muscle taurine content in the mdx mouse model of Duchenne muscular dystrophy using chemically specific synchrotron imaging. Analyst 2020, 145, 7242-7251. [CrossRef]

69. Terrill, J.R.; Grounds, M.D.; Arthur, P.G. Increased taurine in pre-weaned juvenile mdx mice greatly reduces the acute onset of myofibre necrosis and dystropathology and prevents inflammation. PLoS Curr. 2016, 8. [CrossRef]

70. Ladner, C.L.; Yang, J.; Turner, R.J.; Edwards, R.A. Visible fluorescent detection of proteins in polyacrylamide gels without staining. Anal. Biochem. 2004, 326, 13-20. [CrossRef]

71. Schneider, C.A.; Rasband, W.S.; Eliceiri, K.W. NIH Image to ImageJ: 25 years of image analysis. Nat. Methods 2012, 9, 671-675. [CrossRef]

72. Shacter, E.; Williams, J.A.; Lim, M.; Levine, R.L. Differential susceptibility of plasma proteins to oxidative modification: Examination by western blot immunoassay. Free Radic. Biol. Med. 1994, 17, 429-437. [CrossRef]

73. Burch, P.M.; Pogoryelova, O.; Goldstein, R.; Bennett, D.; Guglieri, M.; Straub, V.; Bushby, K.; Lochmüller, H.; Morris, C. Musclederived proteins as serum biomarkers for monitoring disease progression in three forms of muscular dystrophy. J. Neuromuscul. Dis. 2015, 2, 241-255. [CrossRef] [PubMed]

74. Anraku, M.; Chuang, V.T.; Maruyama, T.; Otagiri, M. Redox properties of serum albumin. Biochim. Biophys. Acta 2013, 1830, 5465-5472. [CrossRef]

75. Mukherjee, K.; Chio, T.I.; Sackett, D.L.; Bane, S.L. Detection of oxidative stress-induced carbonylation in live mammalian cells. Free Radic. Biol. Med. 2015, 84, 11-21. [CrossRef] [PubMed]

76. Cipak Gasparovic, A.; Zarkovic, N.; Zarkovic, K.; Semen, K.; Kaminskyy, D.; Yelisyeyeva, O.; Bottari, S.P. Biomarkers of oxidative and nitro-oxidative stress: Conventional and novel approaches. Br. J. Pharmacol. 2017, 174, 1771-1783. [CrossRef] [PubMed]

77. Weber, D.; Davies, M.J.; Grune, T. Determination of protein carbonyls in plasma, cell extracts, tissue homogenates, isolated proteins: Focus on sample preparation and derivatization conditions. Redox Biol. 2015, 5, 367-380. [CrossRef]

78. Himmelfarb, J.; McMonagle, E. Albumin is the major plasma protein target of oxidant stress in uremia. Kidney Int. 2001, 60, 358-363. [CrossRef] [PubMed]

79. Pavone, B.; Sirolli, V.; Giardinelli, A.; Bucci, S.; Forli, F.; Di Cesare, M.; Sacchetta, P.; Di Pietro, N.; Pandolfi, A.; Urbani, A.; et al. Plasma protein carbonylation in chronic uremia. J. Nephrol. 2011, 24, 453-464. [CrossRef] [PubMed]

80. You, T.; Goldfarb, A.H.; Bloomer, R.J.; Nguyen, L.; Sha, X.; McKenzie, M.J. Oxidative stress response in normal and antioxidant supplemented rats to a downhill run: Changes in blood and skeletal muscles. Can. J. Appl. Physiol. 2005, 30, 677-689. [CrossRef]

81. Liu, J.; Yeo, H.C.; Overvik-Douki, E.; Hagen, T.; Doniger, S.J.; Chyu, D.W.; Brooks, G.A.; Ames, B.N. Chronically and acutely exercised rats: Biomarkers of oxidative stress and endogenous antioxidants. J. Appl. Physiol. 2000, 89, 21-28. [CrossRef] [PubMed]

82. Barker, R.G.; Wyckelsma, V.L.; Xu, H.; Murphy, R.M. Mitochondrial content is preserved throughout disease progression in the mdx mouse model of Duchenne muscular dystrophy, regardless of taurine supplementation. Am. J. Physiol. Cell Physiol. 2018, 314, C483-C491. [CrossRef] [PubMed] 
83. Kim, E.Y.; Lee, J.W.; Suh, M.R.; Choi, W.A.; Kang, S.W.; Oh, H.J. Correlation of Serum Creatine Kinase Level with Pulmonary Function in Duchenne Muscular Dystrophy. Ann. Phys. Rehabil. Med. 2017, 41, 306-312. [CrossRef] [PubMed]

84. Zellweger, H.; Antonik, A. Newborn screening for Duchenne muscular dystrophy. Pediatrics 1975, 55, 30-34. [CrossRef] [PubMed]

85. Winterbourn, C.C. Biological reactivity and biomarkers of the neutrophil oxidant, hypochlorous acid. Toxicology 2002, 181-182, 223-227. [CrossRef]

86. Marcinkiewicz, J.; Kontny, E. Taurine and inflammatory diseases. Amino Acids 2014, 46, 7-20. [CrossRef] 